Reprinted with permission from: Plant Disease. August 1990. 74(8):601-604.

Published and copyrighted by: American Phytopathological Society, APS Press. http://www.apsnet.org

\title{
Pathogenicity of Alternaria angustiovoidea on leafy spurge
}

\author{
SHAW-MING YANG, D. R. JOHNSON, and W. M. DOWLER \\ The authors are Research Plant Pathologist, Research Biologist, and Supervisory Plant Pathologist, respectively, For- \\ eign Disease - Weed Science Research Unit, USDA-ARS, Ft. Detrick, Bldg. 1301, Frederick, MD 21701.
}

\begin{abstract}
:
Experiments were conducted as a preclude to the use of Alternaria angustiovoidea as a biological control agent for leafy spurge (Euphorbia esula). A single dew period of at least 12 hours was needed for spores to cause slight infection (a few lesions) on inoculated leaves. To obtain severe infection (dead plants), a single dew period of at least 48 hours was needed. Two successive dew periods of up to 12 hours each did not increase infection over that of a single, 24-hour dew period. Twenty-two out of 25 collections of leafy spurge were susceptible to a single culture of A. angustiovoidea when they were incubated in dew chambers at $20-25^{\circ} \mathrm{C}$ for 48 hours after inoculation. Minor infection also occurred on globe artichoke, corn, cowpea, okra, safflower, and zinnia under the same conditions. A. angustiovoidea produced phytotoxins that caused chlorosis and wilting of leaves on cuttings of leafy spurge placed in the culture filtrate.
\end{abstract}

Leafy spurge (Euphorbia esula L.), a polymorphic complex of many biotypes or species (4), is a perennial weed of the grasslands of North America. The economic losses due to the weed are estimated to be more than 50 million dollars annually in the United States (C. Messersmith, personal communication). Chemical control of the weed is both difficult and costly. The most effective herbicides often cannot be used near other desirable broadleaf species. Therefore, biological control using plant pathogens is being considered as a potential alternative control method.

Alternaria angustiovoidea Simmons (5) has been considered for biological control of leafy spurge (2). We reported (8) preliminary studies on infection of several collections of leafy spurge by this fungus. Ten out of 14 collections of leafy spurge showed resistance to A. angustiovoidea when the inoculated plants were incubated in the dew chamber at $20^{\circ} \mathrm{C}$ for 12 hours (8). Whether or not these resistant collections would become susceptible to $A$. angustiovoidea when a longer dew period is given to the inoculated plants 
is unknown. A. alternata (Fries) Keissler, a causal agent of black leaf blight of spotted knapweed (Centaurea maculosa Lam.), produced a secondary metabolite, maculosin, that is phytotoxic only to spotted knapweed (6). However, it is also unknown whether or not secondary metabolites produced by $A$. angustiovoidea are phytotoxic to leafy spurge.

The objectives of this study were to: 1) determine the effect of different lengths of dew periods on infection of leafy spurge by A. angustiovoidea, 2) study the reaction of different collections of leafy spurge and other plant species to this fungus, and 3) obtain preliminary evidence as to whether this pathogen produces phytotoxins in culture.

\section{Materials and methods}

\section{Preparation of inoculum}

A culture of A. angustiovoidea, originally isolated by Krupinsky and Lorenz (2), was grown on potato-dextrose agar (PDA) or on autoclaved $\left(210^{\circ} \mathrm{C}\right.$ for 30 minutes) leaves of leafy spurge on moistened filter paper in petri dishes and incubated in an incubator at $20^{\circ} \mathrm{C}$ (12 hours light, $90 \mu \mathrm{E} \cdot \mathrm{sec}^{-1} \cdot \mathrm{m}^{-2}$ ). Conidia of A. angustiovoidea were collected from 4- to 5-week-old cultures on PDA or from 2-week-old cultures on autoclaved leaves of leafy spurge by flooding cultures with a sterile, aqueous solution (distilled water $+0.1 \%$ polyoxyethylene sorbitan monolaurate [Tween 20$]+2 \%$ gelatin $+2 \%$ sucrose) and rubbing the surface with a spatula. The combined conidial suspension was filtered through two layers of cheesecloth and adjusted to contain $1 \times 10^{4}$ to $1 \times 10^{5}$ spores per milliliter. Inoculum was atomized onto the plants ( $3 \mathrm{ml}$ for 10 shoots), and the inoculated plants, unless otherwise stated, were immediately incubated in a dew chamber at $20-25^{\circ} \mathrm{C}$ for 48 hours before being moved to greenhouse benches. Control plants were atomized with the sterile aqueous solution.

\section{Growth of leafy spurges}

All leafy spurges used in this study were propagated from two to three root buds in greenhouse mixed soil in 10-cm-diameter clay pots in the containment greenhouse at the Foreign Disease-Weed Science Research Unit at Frederick, MD. The greenhouse soil was prepared by mixing 40 shovels of field soil, 40 shovels of peat moss, 40 shovels of vermiculite, 30 shovels of perlite, 20 shovels of sand, $2 \mathrm{~L}$ of lime stone, $1 \mathrm{~L}$ of fertilizer (10$10-10$ ), and $1 \mathrm{~L}$ of Aqua Grow "G" granular (blended nonionic soil wetting agent, polyethylene ester of cyclic acid [18.8\%], polyethylene ether of alkylated phenols [18.8\%], silicone antiform emulsion [2.4\%], and vermiculite [60\%]; Aquatrols Corp. of America, 1423 Union Ave., Pennsauken, NJ). Water was given every other day. Leafy spurge, at different growth stages before flowering, was used for the inoculation studies. Preliminary studies indicated that the older plants were as susceptible as young plants to $\mathrm{A}$. angustiovoidea. 


\section{Effect of dew periods on infection of leafy spurge}

After inoculation with a conidia suspension of $A$. angustiovoidea, the leafy spurge plants (1982MT000) were placed on greenhouse benches ( 0 hour dew) or in dew chambers $\left(25^{\circ} \mathrm{C}\right)$ in darkness for $2,4,6,12$, or 24 hours before moving to the greenhouse. Each initial dew period was followed by a second dew period of either $0,2,4,6$, or 12 hours, administered 1, 2, 3, or 4 days after the initial dew period. Each treatment had six plants (total of 126 treatments and 756 plants in one test), and the experiment was repeated once.

Disease severity was rated 2 weeks after inoculation. A numerical system, $0-4$, was used to rate the severity where: $0=$ no infection; $1=$ chlorosis or one to two small brown spots on the leaves; $2=$ three to 15 spots on the leaves; $3=$ leaves wilted and easily detached; and $4=$ leaves brown and the plants dying or dead. A disease index score was then calculated by [summation of (severity rating $\times$ number of plants in that rating)]/total number of plants. A disease index at or below 2.9 was considered resistant and that above 2.9 was considered susceptible. After readings were taken, attempts were made to reisolate the pathogen on PDA from tissues cut from selected slightly and severely infected leaves. The tissue pieces $(0.3 \times 0.8 \mathrm{~cm})$ were surface sterilized in $3 \% \mathrm{NaOCI}$ solution for 5-10 minutes, washed in sterile distilled water for 5-10 minutes, placed on PDA plates (four in each plate), and incubated at $20^{\circ} \mathrm{C}$ for 34 weeks. Presence of $A$. angustiovoidea was determined by examining conidia under the microscope.

In another experiment, inoculated plants of collection 1982MT000 were either given a dew period of $0,6,12,24$, or 48 hours, or they were placed in the greenhouse for 1,2 , 3 , or 4 days before they were given a dew period of $0,6,12,24$, or 48 hours. Each treatment had five plants (total of 125 plants per test), and the test was repeated once. Disease severity was determined 2 weeks after inoculation.

\section{Inoculation of collections of leafy spurge and other plant species}

Leafy spurge was collected from Europe and the United States by W.L. Bruckart, D.G. Davis, R.M. Hosford, S.K. Turner, and R. Vonmoos. The collections were numbered following the system proposed by Davis (1): the year of collection followed by a one- or two-letter designation for country or state of origin and a 3-digit number showing the sequence of collections. Sixteen to 24 plants of each collection in two tests were inoculated with $A$. angustiovoidea and incubated in dew chambers at $25^{\circ} \mathrm{C}$ for 48 hours.

Seedlings of other plant species, alfalfa (Medicago sativa L.) cv. Williamburg, artichoke (Cynara scolymus L.) cv. Green Globe, corn (Zea mays L.) cv. 3369A, cowpea (Vigna sinensis (L.) Engl.) cv. California blackeye, jute (Corchorus capsularis L.), mung bean (Phaseolus aureus Roxb.), oats (Avena sativa L.) cv. Clinton, okra (Hibiscus esculentus L.) cv. Cleanson spineleso, peanut (Arachis hypogaea L.) cv. Wilco 1, rice (Oryza sativa L.) cv. M201, safflower (Carthamus tinctorius L.) cv. Pacific 1, sorghum (Sorghum bicolor L.) cv. Top Hand, sunflower (Helianthus annuus) cv. 894, wheat (Triticum aestivum L.) cv. Max, and zinnia (Zinnia grandiflora Nutt.) cv. Cupid, were also inocu- 
lated with $A$. angustiovoidea and incubated in dew chambers at $25^{\circ} \mathrm{C}$ for 12,24 , or 48 hours. Five plants of each species were inoculated each time, and the test was repeated once. Readings were taken 2 weeks after inoculation.

\section{Bioassay for phytotoxin production}

A small piece of agar with mycelium taken from the edge of 3- to 4-day-old cultures on PDA was placed in each 250-ml flask (total of 10 flasks in each test) containing $50 \mathrm{ml}$ of Fries liquid medium (7) minus lithium chloride. Flasks containing only Fries medium served as controls. The flasks were placed in an incubator (12 hours light, $20 \mu \mathrm{E} \cdot \mathrm{sec}^{-1} \cdot \mathrm{m}^{-2} /$ day) at $25^{\circ} \mathrm{C}$. After 1-2 weeks of incubation, the cultures in each flask were separately centrifuged at $6,600 \mathrm{rpm}$ for 10 minutes to pellet the mycelium. The supernatant in each centrifuge tube was separately passed through a membrane filter (pore size $0.45 \mathrm{gm}$ ) and collected in $15-\mathrm{ml}$ sterile polypropylene centrifuge tubes. The stem end of a healthy shoot of leafy spurge freshly cut from greenhouse-grown plants was immediately immersed in the solution and held at $20 \pm 2^{\circ} \mathrm{C}$ with 10 hours light, $9.5 \mu \mathrm{E} \cdot \mathrm{sec}^{-1} \bullet \mathrm{m}^{-2} /$ day. Cuttings placed in the Fries medium from the control flasks or distilled water served as controls. Cuttings were examined 24-48 hours later to observe reactions. Chlorosis and wilting of leaves was assumed to indicate the presence of phytotoxins in the culture filtrate. The objective of this study was to obtain preliminary evidence of phytotoxins produced by this pathogen; therefore, only presence or absence of symptoms was scored. This test was repeated twice.

\section{Results and discussion}

\section{Effect of dew periods on infection of leafy spurge}

Both runs of the experiment produced similar results and data were pooled (Table 1). An initial dew period of 6 hours or less and a second dew period of 12 hours or less did not allow disease to develop (Table 1). A single dew period of at least 12 hours was needed to cause slight infection (a few spots on inoculated leaves) on leafy spurge (Tables 1 and 2). Leafy spurge given a 24-hour dew period after inoculation had significantly greater disease severity than that given a 12-hour dew period (Tables 1 and 2). Similarly, leafy spurge that received a second dew period of 24 hours (1-4 days after an initial 24hour dew period given soon after inoculation) also had significantly greater disease severity than leafy spurge that received a second dew period of 12 hours. Severity of disease on leafy spurge receiving a second 12-hour dew period 1 day after an initial 12-hour dew period was similar to that of plants receiving a single 24-hour dew period. When the second 12 -hour or 24-hour dew period was given 2,3 , or 4 days after inoculation, the severity of disease was significantly reduced. 
Table 1. Effect of length of initial dew period and length and time of second dew periods on severity of disease ${ }^{\mathrm{x}}$ on leafy spurge inoculated with Alternaria angustiovoidea at $20-25^{\circ} \mathrm{C}$.

\begin{tabular}{|c|c|c|c|c|c|c|c|c|}
\hline \multicolumn{2}{|c|}{ Second dew period } & \multicolumn{6}{|c|}{ Initial dew length (hr) } & \multirow{2}{*}{$\begin{array}{c}\text { LSD }^{\mathrm{y}} \\
(P=0.05)\end{array}$} \\
\hline Days after initial dew & Length (hr) & 0 & 2 & 4 & 6 & 12 & 24 & \\
\hline 0 & & 0 & 0 & 0 & 0 & $1.5^{\mathrm{z}} \mathrm{cd}$ & $2.5 \mathrm{c}$ & 0.6 \\
\hline \multirow[t]{5}{*}{1} & 0 & 0 & 0 & 0 & 0 & $1.4 \mathrm{~cd}$ & $2.5 \mathrm{c}$ & 0.6 \\
\hline & 2 & 0 & 0 & 0 & 0 & $1.8 \mathrm{bc}$ & $2.5 \mathrm{c}$ & 0.6 \\
\hline & 4 & 0 & 0 & 0 & 0 & $1.9 \mathrm{bc}$ & $2.9 \mathrm{~b}$ & 0.8 \\
\hline & 6 & 0 & 0 & 0 & 0 & $2.8 \mathrm{a}$ & $2.8 \mathrm{bc}$ & 0.6 \\
\hline & 12 & 0 & 0 & 0 & 0 & $2.3 \mathrm{ab}$ & $3.3 \mathrm{a}$ & 0.9 \\
\hline \multirow[t]{5}{*}{2} & 0 & 0 & 0 & 0 & 0 & $1.3 \mathrm{~cd}$ & $2.5 \mathrm{c}$ & 0.9 \\
\hline & 2 & 0 & 0 & 0 & 0 & $1.5 \mathrm{~cd}$ & $2.7 \mathrm{bc}$ & 0.9 \\
\hline & 4 & 0 & 0 & 0 & 0 & $1.3 \mathrm{~cd}$ & $2.8 \mathrm{~b}$ & 0.9 \\
\hline & 6 & 0 & 0 & 0 & 0 & $1.3 \mathrm{~cd}$ & $2.9 \mathrm{~b}$ & 0.9 \\
\hline & 12 & 0 & 0 & 0 & 0 & $1.2 \mathrm{~cd}$ & $2.9 \mathrm{~b}$ & 0.6 \\
\hline \multirow[t]{5}{*}{3} & 0 & 0 & 0 & 0 & 0 & $1.5 \mathrm{~cd}$ & $2.7 \mathrm{bc}$ & 0.6 \\
\hline & 2 & 0 & 0 & 0 & 0 & $1.3 \mathrm{~cd}$ & $2.7 \mathrm{bc}$ & 0.6 \\
\hline & 4 & 0 & 0 & 0 & 0 & $1.4 \mathrm{~cd}$ & $2.5 \mathrm{c}$ & 0.6 \\
\hline & 6 & 0 & 0 & 0 & 0 & $1.5 \mathrm{~cd}$ & $2.8 \mathrm{bc}$ & 0.6 \\
\hline & 12 & 0 & 0 & 0 & 0 & $1.4 \mathrm{~cd}$ & $2.9 \mathrm{~b}$ & 1.4 \\
\hline \multirow[t]{5}{*}{4} & 0 & 0 & 0 & 0 & 0 & $1.6 \mathrm{c}$ & $2.5 \mathrm{c}$ & 0.9 \\
\hline & 2 & 0 & 0 & 0 & 0 & $1.2 \mathrm{~d}$ & $2.5 \mathrm{c}$ & 0.6 \\
\hline & 4 & 0 & 0 & 0 & 0 & $1.6 \mathrm{c}$ & $2.9 \mathrm{~b}$ & 0.6 \\
\hline & 6 & 0 & 0 & 0 & 0 & $1.5 \mathrm{~cd}$ & $2.7 \mathrm{bc}$ & 0.9 \\
\hline & 12 & 0 & 0 & 0 & 0 & $1.5 \mathrm{~cd}$ & $2.9 \mathrm{~b}$ & 0.9 \\
\hline
\end{tabular}

${ }^{\mathrm{x}}$ Disease index was calculated from [summation of (severity rating $\times$ number of plants in the rating)]/total number of plants. A numerical system, 0-4, was used to rate the severity of disease. Average of 12 plants in each treatment in two tests.

${ }^{\mathrm{y}} \operatorname{LSD}(P=0.05)$ used to compare the paired means of dew at 12 and 24 hours in the same row.

${ }^{z}$ Numbers followed by the same letter in a column are not significantly different according to Duncan's new multiple range test $(P=0.05)$.

To cause severe infection (dying or dead plants), a single dew period of at least 48 hours was needed (Table 2). When an initial 12-hour dew period was delayed 2 days or more after inoculation, there was no infection. When an initial 24-hour or 48-hour dew period was delayed up to 4 days after inoculation, the disease severity was similar to that of plants that received dew periods immediately after inoculation. Both runs of the experiment gave similar results, and data were pooled. $A$. angustiovoidea required dew periods of at least 48 hours at $20-25^{\circ} \mathrm{C}$ for severe disease development; this may be one of the reasons why the pathogen does not become epidemic on leafy spurge in the Great Plains. The pathogen was reisolated from all of the selected severely infected plants but from only $40 \%$ of slightly infected plants. 
Table 2. Effect of delaying initial dew period on severity of disease on leafy spurge inoculated with Alternaria angustiovoidea.

\begin{tabular}{cccccc}
\hline & \multicolumn{5}{c}{ Hours in dew chamber at $25^{\circ} \mathrm{C}$} \\
\cline { 2 - 6 } Initial dew given after inoculation (days) & 0 & 6 & 12 & 24 & 48 \\
\hline 0 & $0 \mathrm{z}^{\mathrm{a}}$ & $0 \mathrm{z}^{\mathrm{b}}$ & $1.5 \mathrm{ay}$ & $2.4 \mathrm{ax}$ & $4.0 \mathrm{aw}$ \\
1 & $0 \mathrm{z}$ & $0 \mathrm{z}$ & $0.6 \mathrm{by}$ & $1.5 \mathrm{ax}$ & $4.0 \mathrm{aw}$ \\
2 & $0 \mathrm{y}$ & $0 \mathrm{y}$ & $0.0 \mathrm{cy}$ & $2.1 \mathrm{ax}$ & $3.9 \mathrm{aw}$ \\
3 & $0 \mathrm{y}$ & $0 \mathrm{y}$ & $0.0 \mathrm{cy}$ & $1.9 \mathrm{ax}$ & $3.8 \mathrm{aw}$ \\
4 & $0 \mathrm{y}$ & $0 \mathrm{y}$ & $0.0 \mathrm{cy}$ & $1.9 \mathrm{ax}$ & $4.0 \mathrm{aw}$ \\
\hline
\end{tabular}

${ }^{\mathrm{a}}$ Disease index was calculated from [summation of (severity rating $\times$ number of plants in the rating)]/total number of plants. A numerical system, 0-4, was used to rate the severity of disease. Average of 10 plants in two tests.

${ }^{b}$ Numbers followed by the same letter (abc for same column, and wxyz for same row) are not significantly different according to Duncan's new multiple range test $(P=0.05)$.

\section{Inoculation of collections of leafy spurge and other plant species}

Twenty-two out of 25 leafy spurge collections were rated susceptible to A. angustiovoidea when inoculated plants were incubated for 48 hours in the dew chamber (Table 3). Susceptible leafy spurge included those collections from Austria, Italy, Turkey, Yugoslavia, Idaho, Maryland, Massachusetts, Michigan, Minnesota, Montana, Nevada, New Jersey, North Dakota, and Oregon. Both resistant and susceptible individual plants were found in populations of one collection from Austria (1978A001), one from Canada (1982BC001), and one from Turkey (1982TU002). It is not known whether resistant individuals would show a susceptible reaction to a different culture of the fungus. The 10 collections of leafy spurge that showed resistance to A. angustiovoidea at $20^{\circ} \mathrm{C}$ in a dew chamber for 12 hours (8) also became susceptible to this pathogen when the plants were incubated in dew chambers at $25^{\circ} \mathrm{C}$ for 48 hours (unpublished). This result confirms the previous experiments that this pathogen requires an extended dew period for inducing severe disease on leafy spurge. Control plants showed no symptoms of the disease. The pathogen was reisolated from all of the selected severely infected plants. However, the pathogen was reisolated from only $30-50 \%$ of the selected leafy spurge plants that gave a resistant reaction. The pathogen was not isolated from the control plants. The repeat experiment produced similar results, and data were pooled (Table 3).

A. angustiovoidea did not infect alfalfa, jute, peanut, rice, sorghum, sunflower, or wheat, but it induced a few spots on globe artichoke, corn, cowpea, mung bean, oats, okra, safflower, and zinnia when the inoculated plants were incubated in dew chambers at $25^{\circ} \mathrm{C}$ for 48 hours. The pathogen also was reisolated from infected plants of these species. However, infection was not found on these species when the inoculated plants were given 12-hour and 24-hour dew periods.

The fungus used in this study infected plants other than leafy spurge only after an extended dew period. It will be important to compare disease severity on the various hosts under field conditions to determine their relative susceptibility if this fungus is to be used as a candidate for a mycoherbicide. 


\section{Bioassay for phytotoxin production}

A. angustiovoidea appeared to produce phytotoxins in the Fries liquid medium (Fig. 1). The pathogen produced the toxin(s) in vitro within 1 week at $25^{\circ} \mathrm{C}$, but 2 -week-old cultures also had phytotoxic activity. Phytotoxic activity was seen in 27 of the 30 flaskcultures in three tests. The three flask-cultures that showed no activity were contaminated either with bacteria or other fungal species. Chlorosis of leaves and wilting were observed 24 hours after exposing the leafy spurge cutting to the culture filtrate. The phytotoxins are not apparently host specific because partially purified toxin also caused chlorosis on duckweed (Lemna obscura L.) (3). The characteristics, structure, and efficacy of the toxins for control of leafy spurge in the greenhouse are under investigation.

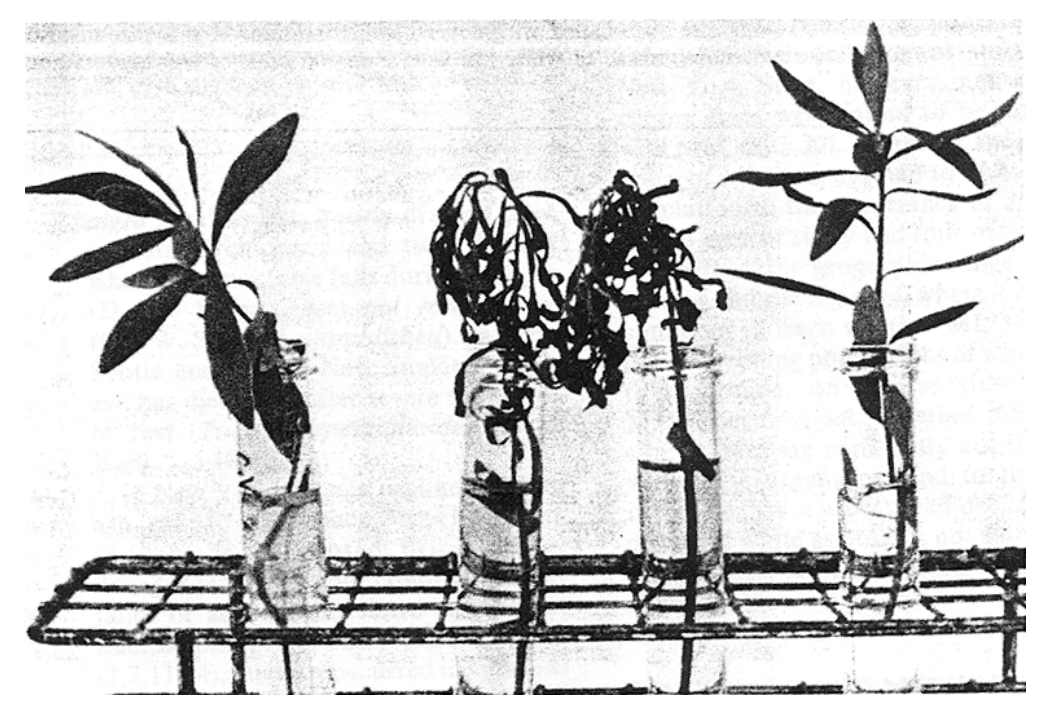

Fig. 1. Wilting of leaves on cuttings of leafy spurge when immersed in the culture filtrate of Alternaria angustiovoidea. Left, cutting in sterile Fries culture medium; center, two cuttings in culture filtrates; and right, cutting in sterile distilled water. Photo was taken 48 hours after exposure.

Our results with $A$. angustiovoidea, and similar results obtained by others (2), suggest that this fungus might be useful in biological control of leafy spurge. However, before considering large-scale field trials, knowledge should be gathered about 1) how to increase the effectiveness of $A$. angustiovoidea on leafy spurge, 2) potential secondary spread of the fungus, 3) overwintering ability, and 4) the potential for damage to nontarget crops. 
Table 3. Reaction of leafy spurge (Euphorbia esula) collections to inoculation with Alternaria angustovoidea ${ }^{a}$.

\begin{tabular}{|c|c|c|}
\hline Collection $^{\mathrm{b}}$ & Origin (country or state) & Disease index ${ }^{c}$ \\
\hline 1977A001 & Austria & 3.6 \\
\hline 1978A001 & Austria & 2.3 \\
\hline $1981 \mathrm{I} 002$ & Italy & 3.8 \\
\hline 1982TU001 & Turkey & 4.0 \\
\hline 1982TU002 & Turkey & 2.3 \\
\hline 1982YU001 & Yugoslavia & 4.0 \\
\hline 1978ID001 & Idaho & 4.0 \\
\hline 1978ID002 & Idaho & 3.8 \\
\hline 1982MA001 & Massachusetts & 4.0 \\
\hline 1982MD001 & Maryland & 4.0 \\
\hline 1978MI001 & Michigan & 3.9 \\
\hline 1979MN001 & Minnesota & 3.7 \\
\hline 1979MN007 & Minnesota & 4.0 \\
\hline 1979MN008 & Minnesota & 4.0 \\
\hline 1982MT000 & Montana & 3.5 \\
\hline 1979NE001 & Nebraska & 4.0 \\
\hline 1979NE002 & Nebraska & 4.0 \\
\hline 1988NE001 & Nebraska & 4.0 \\
\hline 1978NV001 & Nevada & 3.7 \\
\hline 1982NJ001 & New Jersey & 3.5 \\
\hline 1982NJ002 & New Jersey & 3.9 \\
\hline 1979ND006 & North Dakota & 3.5 \\
\hline 1986ND001 & North Dakota & 3.5 \\
\hline 1978OR001 & Oregon & 3.8 \\
\hline \multirow[t]{2}{*}{ 1982BC001 } & British Columbia, & \\
\hline & Canada & 2.8 \\
\hline $\begin{array}{l}{ }^{2} \text { Inoculated plants were incub } \\
\text { for an additional } 12 \text { days. } \\
{ }^{b} \text { Collection numbers consist } \\
\text { of origin, and by a } 3 \text {-digit nur } \\
{ }^{c} \text { Disease index was calculatec } \\
\text { plants. A numerical system, } 0 \\
\text { of } 16-24 \text { plants of each collec }\end{array}$ & $\begin{array}{l}\text { ers at } 25^{\circ} \mathrm{C} \text { for } 48 \text { hours befo } \\
\text { tion, followed by a one- or th } \\
\text { equence of the collection. } \\
\text { of (severity rating } \times \text { number }\end{array}$ & $\begin{array}{l}\text { on greenhouse } b \\
\text { ation for country } \\
\text { rating)]/total num } \\
\text { istant reaction). A }\end{array}$ \\
\hline
\end{tabular}

Page 8 of 9 


\section{Literature cited}

1. Davis, D. G. 1985. The status of the leafy spurge numbering system. Pages 1-2 in: Proceedings of the Leafy Spurge Symposium, 1985. Montana State Univ., Bozeman. July 17 and 18.

2. Krupinsky, J. M., and Lorenz, R. J. 1983. An Alternaria sp. on leafy spurge (Euphorbia esula). Weed Sci. 31:86-88.

3. Leather, G. R., Yang, S. M., and Dowler, W. M. 1989. Control of leafy spurge with natural chemical products. Pages 46-50 in: Proceedings of the Leafy Spurge Symposium, 1989. Montana State Univ., Bozeman. July 12 and 13.

4. Radcliffe-Smith, A. 1985. Taxonomy of North American leafy spurge. Pages 14-25 in: Leafy Spurge. A.K. Watson, ed. Weed Science Society of America, Champaign. IL.

5. Simmons, E. G. 1986. Alternaria themes and variations (14-16). Mycotaxon 25:195-202.

6. Stierle, A., Cardellina, J., II, Park, S. H., and Strobel, G. 1989. Maculosin, a host specific toxin from Alternaria alternata on spotted knapweed. Agrochemicals Division 105. Book of Abstracts, 197th ACS National Meeting, Dallas, TX. April 9-14,1989, ACS, Washington, D.C.

7. Tuite, J. 1969. Plant Pathological Methods. Fungi and Bacteria. Burgess Publishing Co., Minneapolis, MN. 239 pp.

8. Yang, S. M., Johnson, D. R., Dowler, W. M., and Krupinsky, J. M. 1988. Reaction of different biotypes of leafy spurge and other plant species to Alternaria tenuissima f. sp. euphorbiae. Pages 56-58 in: Proceedings of the Leafy Spurge Symposium, 1988. South Dakota State Univ., Brookings. July $12-13$. 